\title{
Effects of calcium salts of polyunsaturated fatty acids on productive and reproductive parameters of lactating Holstein cows
}

\author{
M. M. Reis, ${ }^{\star}$ R. F. Cooke, $†$ J. Ranches, ${ }^{*}$ and J. L. M. Vasconcelos ${ }^{\star 1}$ \\ *São Paulo State University-Department of Animal Production, Botucatu 18168-000, Brazil \\ †Oregon State University-Eastern Oregon Agricultural Research Center, Burns 97720
}

\begin{abstract}
Two experiments evaluated milk production, serum progesterone and insulin, and reproductive performance of lactating Holstein cows receiving or not receiving $\mathrm{Ca}$ salts of polyunsaturated fatty acids (PUFA), or receiving $\mathrm{Ca}$ salts of PUFA at different daily frequencies. In experiment $1,1,125$ cows randomly distributed in 10 freestall barns were enrolled. Barns were assigned randomly to receive a high-concentrate diet containing (PF) or not containing (control, CON) 1.1\% (dry matter basis) Ca salts of PUFA. Diets were offered 6 times daily, whereas the Ca salts of PUFA were included in the PF treatment in the first feeding of the day. In experiment 2, 1,572 cows were randomly distributed in 10 freestall barns, which were assigned randomly to receive a diet similar to $\mathrm{PF}$, but with Ca salts of PUFA included only in the first feeding of the day (PF1X), or equally distributed across all 6 feedings (PF6X). During both experiments, cows were artificially inseminated 12 $\mathrm{h}$ after the onset of estrus. Once per month, cows that did not conceive to artificial insemination were assigned to a fixed-time embryo transfer protocol. Pregnancy was determined via transrectal ultrasonography 28 and $60 \mathrm{~d}$ after expected ovulation. Pregnancy loss was considered in cows that were pregnant on d 28 but nonpregnant on d 60. During both experiments, feed intake, milk yield, and milk protein and fat content were recorded weekly. Blood samples were collected concurrently with embryo transfer. During experiment 1 , feed intake was similar between treatments. Compared with $\mathrm{CON}, \mathrm{PF}$ cows had greater milk yield ( 37.8 vs. $35.3 \mathrm{~kg} / \mathrm{d}$ ), and reduced milk fat content (3.41 vs. $3.55 \%$ ). However, PF cows had reduced pregnancy losses per service compared with CON (12.6 vs. 18.3\%). Serum progesterone was greater and serum insulin tended to be greater in primiparous cows receiving $\mathrm{PF}$ compared with $\mathrm{CON}$
\end{abstract}

Received March 4, 2012.

Accepted August 17, 2012.

${ }^{1}$ Corresponding author: vasconcelos@fmvz.unesp.br cohorts (4.50 vs. $3.67 \mathrm{ng}$ of progesterone/mL, and 10.4 vs. $7.5 \mu \mathrm{UI}$ of insulin/mL). During experiment 2, no treatment effects were detected for feed intake, milk yield, or milk fat, whereas PF1X cows tended to have reduced pregnancy losses per service compared with PF6X (14.4 vs. 18.4\%). In summary, feeding Ca salts of PUFA to dairy cows increased milk production, did not alter feed intake, and reduced pregnancy losses per service. Further, the total daily amount of $\mathrm{Ca}$ salts of PUFA should be fed during the first feeding of the day to optimize its benefits on pregnancy maintenance of dairy cows.

Key words: dairy cow, polyunsaturated fatty acid, production, reproduction

\section{INTRODUCTION}

During the last few decades, milk production per dairy cow has increased, whereas reproductive efficiency has decreased (Lucy, 2001). Given that nutrition greatly affects productive and reproductive functions (Butler, 2005), nutritional strategies that promote milk production and concurrently benefit, or at least sustain, reproductive efficiency of dairy cows and heifers are warranted. As an example, inclusion of Ca salts of FA increased overall milk production of dairy cows (Erickson et al., 1992; Chouinard et al., 1997; Moallem et al., 2000). Our research group demonstrated that supplementing Ca salts of PUFA during early gestation increased pregnancy rates in beef cows assigned to AI or embryo transfer by at least 10 percentage points (Lopes et al., 2009, 2011). Moreover, these reproductive benefits of PUFA supplementation to cattle were independent of its contribution to dietary energy content (Staples and Thatcher, 2005; Lopes et al., 2011).

Beneficial postbreeding effects of PUFA include increased circulating progesterone $(\mathbf{P} 4)$ concentrations (Grummer and Carroll, 1991; Lopes et al., 2009) and enhanced pregnancy maintenance (Spencer and Bazer, 2002; Lopes et al., 2011). More specifically, PUFA have been shown to increase circulating $\mathrm{P} 4$ concentrations during early gestation by enhancing development of 
luteal cells (Lucy et al., 1991) and directly alleviating hepatic steroid metabolism (Sangsritavong et al., 2002). Supplemental PUFA may also increase circulating insulin concentrations (Williams and Stanko, 2000), which in turn has also been shown to reduce hepatic expression of P4 catabolic enzymes (Lemley et al., 2008; Vieira et al., 2010) and improve dairy reproductive function (Gong et al., 2002). However, Ca salts of PUFA can be substantially dissociated and biohydrogenated when ruminal pH is below 6.0 (Sukhija and Palmquist, 1990). In dairy cows receiving high-concentrate diets, ruminal $\mathrm{pH}$ can be rapidly reduced, and remain below 6.0 for several hours after feeding (Leedle et al., 1982). Maekawa et al. (2002) reported the ruminal pH in dairy cows receiving high-concentrate TMR was greater than 6.0 before the morning feeding, remained above this level for at least $3 \mathrm{~h}$ after the morning feeding, but was less than 6.0 for the remainder of the day.

Based on this information, we hypothesized that feeding Ca salts of PUFA will benefit milk production and reproductive efficiency of dairy cows, and this outcome can be attributed, at least in part, to increased circulating P4 concentrations during early gestation. We also hypothesized that Ca salts of PUFA should be fed during the first feeding of the day to alleviate or prevent ruminal biohydrogenation and optimize the benefits of PUFA supplementation to dairy cows receiving high-concentrate diets. Hence, 2 experiments were conducted to evaluate milk production, milk composition, postbreeding serum concentrations of P4 and insulin, and reproductive performance of lactating Holstein cows receiving or not receiving Ca salts of PUFA (experiment 1), or receiving Ca salts of PUFA at different daily frequencies (experiment 2).

\section{MATERIALS AND METHODS}

Both experiments were conducted at a commercial dairy farm located in Araras, São Paulo, Brazil. The latitude, longitude, and altitude of this location are, respectively, $22^{\circ} 21^{\prime}$ south, $47^{\circ} 23^{\prime}$ west, and $614 \mathrm{~m}$. Experiment 1 was conducted from April 2009 to March 2010, whereas experiment 2 was conducted from April 2010 to June 2011. The animals used were cared for in accordance with the practices outlined in the Guide for the Care and Use of Agricultural Animals in Agricultural Research and Teaching (FASS, 1999). Across experiments, cows were maintained in freestall barns with access to an adjoining sod-based area. Barns were cooled by intermittent sprinkling and forced ventilation to minimize the effects of heat stress. Cows were milked 3 times daily in a side-by-side milking system (0400, 1200 , and $2000 \mathrm{~h})$.

\section{Animals and Treatments}

Experiment 1. A total of 1,125 primiparous ( $\mathrm{n}=$ $376)$ and multiparous $(\mathrm{n}=749)$ lactating Holstein cows $(170 \pm 3$ DIM) randomly distributed in 10 freestall barns were enrolled in the experiment. Beginning in April 2009, freestall barns were assigned randomly to receive a high-concentrate diet containing $(\mathbf{P F})$ or not containing (control, CON) 1.1\% (DM basis) Ca salts of PUFA (Megalac-E; Química Geral do Nordeste, Rio de Janeiro, Brazil). Diets were offered as TMR 6 times daily (0400, 0600, 0800, 1200, 1500, and 2000 h), whereas the Ca salts of PUFA were included in the PF treatment in the first feeding of the day $(0400$ h; Table 1). The FA profile of treatments (Table 2) was estimated based on feed values provided by the CPM-Dairy model (Cornell-Penn-Miner Dairy, version 3.08.01; University of Pennsylvania, Kennett Square; Cornell University, Ithaca, NY; and William H. Miner Agricultural Research Institute, Chazy, NY), and the FA content of the Ca salts of PUFA provided by the manufacturer. Treatments were offered until March 2010, whereas cows remained in their original freestall barn throughout lactation. Within the cows enrolled in this experiment, a total of 691 animals (primiparous, $\mathrm{n}=227$; multiparous, $\mathrm{n}=464$ ) received treatments beginning at 30 DIM after being managed similarly during the initial $30 \mathrm{~d}$ postpartum, whereas the remaining 434 animals (primiparous, $\mathrm{n}=149$; multiparous, $\mathrm{n}$ $=285)$ began receiving treatments at greater DIM (170 \pm 6 DIM).

Experiment 2. A total of 1,572 primiparous (n = $622)$ and multiparous $(\mathrm{n}=950)$ lactating Holstein cows $(155 \pm 4$ DIM) randomly distributed in 10 freestall barns were enrolled in the experiment. Beginning in April 2010, freestall barns were assigned randomly to receive a diet similar to $\mathrm{PF}$ in experiment 1 (Table 1 ), but with Ca salts of PUFA included only in the first feeding of the day (0400 h; PF1X), or equally distributed across all feedings (PF6X). As in experiment 1, diets were offered as TMR 6 times daily (0400, 0600, 0800, 1200, 1500, and $2000 \mathrm{~h}$ ), and the Ca salts of PUFA was included into both treatments at $1.1 \%$ (DM basis). Cows that were enrolled in experiment 1 receiving PF were automatically enrolled in experiment 2 as PF1X. Treatments were offered until June 2011, and cows remained in their original freestall barn throughout the lactation. Within the cows enrolled in this experiment, 1,085 animals (primiparous, $\mathrm{n}=435$; multiparous, $\mathrm{n}=650$ ) received treatments beginning at 30 DIM after being managed similarly during the initial $30 \mathrm{~d}$ postpartum, whereas the remaining 487 animals (primiparous, $\mathrm{n}=187$; multiparous, $\mathrm{n}=300$ ) began receiving treatments at greater DIM $(187 \pm 6$ DIM $)$. 
Table 1. Composition and nutritional profile of diets enriched (PF) or not enriched (control) with Ca salts of PUFA, offered to lactating dairy cows in experiments 1 and 2

\begin{tabular}{lcc}
\hline Item & Control & PF \\
\hline Ingredient, \% of DM & & \\
Corn silage & 32.7 & 35.3 \\
Grass hay & 3.7 & 4.7 \\
Whole cottonseed & 11.9 & 6.0 \\
Citrus pulp & 13.8 & 13.9 \\
High-moisture corn & 6.7 & 6.8 \\
Cracked corn & 9.5 & 9.6 \\
Soybean meal & 14.5 & 15.3 \\
Whole soybean & 4.0 & 4.0 \\
Ca salts of PUFA ${ }^{1}$ & 0.0 & 1.1 \\
Mineral and vitamin mix ${ }^{2}$ & 3.2 & 3.3 \\
Nutrient profile, ${ }^{3}$ DM basis & & \\
NE ${ }_{\mathrm{L}}{ }^{4}$ MCal/kg & 1.76 & 1.78 \\
NE ${ }_{\mathrm{M}}{ }^{4}$ MCal/kg & 1.76 & 1.78 \\
CP, $\%^{\text {NDF, } \%}$ & 17.5 & 16.9 \\
Ether extract, \% & 31.9 & 31.1 \\
Ca, \% & 5.7 & 5.7 \\
P, \% & 1.00 & 1.1 \\
\hline
\end{tabular}

${ }^{1}$ Megalac-E (Química Geral do Nordeste, Rio de Janeiro, Brazil).

${ }^{2}$ Contained $7.7 \% \mathrm{Ca}, 4.0 \% \mathrm{P}, 3.0 \% \mathrm{Na}, 0.20 \% \mathrm{~K}, 0.20 \% \mathrm{Mg}, 2.0 \% \mathrm{~S}$, $0.002 \%$ Co, $0.03 \% \mathrm{Cu}, 0.002 \% \mathrm{I}, 0.02 \% \mathrm{Mn}, 0.13 \% \mathrm{Zn}$, and $0.02 \% \mathrm{~F}$.

${ }^{3}$ Values were obtained from a commercial laboratory using wet chemistry analysis (Nutron, Campinas, Brazil).

${ }^{4}$ Calculated with the following equations (NRC, 2011): $\mathrm{NE}_{\mathrm{M}}=1.37$ $\mathrm{ME}-0.138 \mathrm{ME}_{2}+0.0105 \mathrm{ME}_{3}-1.12 ; \mathrm{NE}_{\mathrm{G}}=1.42 \mathrm{ME}-0.174 \mathrm{ME}_{2}$ $+0.0122 \mathrm{ME}_{3}-0.165$, given that $\mathrm{ME}=0.82 \times \mathrm{DE}$, and $1 \mathrm{~kg}$ of TDN $=4.4 \mathrm{Mcal}$ of $\mathrm{DE} . \mathrm{DE}=$ digestible energy.

\section{Reproductive Management}

During both experiments, cows that were $>60$ DIM were monitored for estrus using commercial pedometers (AfiTag; AfiMilk, Kibbutz Afikim, Israel), and artificially inseminated $12 \mathrm{~h}$ after the onset of estrus. Cows were inseminated by a single experienced technician using commercial frozen-thawed semen randomly chosen from 1 of 18 sires. A total of 1,739 AI were performed in 764 cows during experiment 1, whereas in experiment 2, 3,044 AI were performed in 1,133 cows. Pregnancy diagnosis was performed by detecting a viable conceptus with transrectal ultrasonography (Aloka SSD-500, 7.5 MHz linear-array transrectal transducer; Aloka Co. Ltd., Tokyo, Japan) 28 and $60 \mathrm{~d}$ after AI. Pregnancy loss was considered in cows that were pregnant on $\mathrm{d} 28$ but nonpregnant on d 60 after AI.

During both experiments, cows ( $>60$ DIM) that were not assigned AI or were diagnosed as nonpregnant (d 28 or 60 after $\mathrm{AI}$ ) were assigned to an ovulation synchronization + fixed-time embryo transfer (FTET) protocol once a month. For the ovulation synchronization protocol (beginning on $\mathrm{d}-10$ ), cows received a $100-\mu \mathrm{g}$ injection of GnRH (Fertagyl; Schering-Plough Co., São Paulo, Brazil) and received an intravaginal $\mathrm{P} 4$ releasing device [controlled internal drug release (CIDR), con-
Table 2. Fatty acid profile of diets enriched (PF) or not enriched (control) with Ca salts of PUFA, offered to lactating dairy cows in experiments 1 and $2^{1}$

\begin{tabular}{lcc}
\hline FA, \% & Control & PF \\
\hline Palmitic acid (16:0) & 19.8 & 18.3 \\
Stearic acid (18:0) & 2.8 & 3.4 \\
Oleic acid (18:1) & 17.8 & 21.1 \\
Linoleic acid (18:2) & 52.8 & 49.2 \\
Linolenic acid (18:3) & 4.2 & 5.1 \\
Other & 2.6 & 2.9 \\
\hline
\end{tabular}

${ }^{1}$ Calculated using values provided by the CPM-Dairy model (CornellPenn-Miner Dairy, version 3.08.01; University of Pennsylvania, Kennett Square; Cornell University, Ithaca, NY; and William H. Miner Agricultural Research Institute, Chazy, NY) and FA content of the Ca salts of PUFA (Megalac-E; Química Geral do Nordeste, Rio de Janeiro, Brazil) provided by the manufacturer.

taining $1.9 \mathrm{~g}$ of P4; Pfizer Animal Health, São Paulo, Brazil] on d -10, a 25-mg injection of $\mathrm{PGF}_{2 \alpha}$ (Lutalyse; Pfizer Animal Health) and CIDR removal on $\mathrm{d}-3$, and a 1-mg injection of estradiol cypionate (ECP; Pfizer Animal Health) on d -2 . Transrectal ultrasonography examinations (Aloka SSD-500, 7.5 MHz linear-array transrectal transducer) were performed in all recipient cows immediately before FTET (d 7) to verify presence of a corpus luteum. Only cows detected with a visible corpus luteum were assigned to embryo transfer (ET), which was performed with fresh Holstein embryos originated from in vivo procedures and obtained from a private company (Policlinica Pioneiros, Paraná, Brazil). Embryo collection and ET procedures were similar to those described by Vasconcelos et al. (2011), and embryos originated from a combination of 75 donors (nonlactating heifers and cows) and 7 sires. Embryo transfer was performed by a single experienced technician and embryos were assigned randomly to recipient cows. A total of 978 FTET were performed in 632 cows during experiment 1, whereas in experiment 2, 1,171 FTET were performed in 697 cows. Pregnancy diagnosis was performed by detecting a viable conceptus with transrectal ultrasonography (Aloka SSD-500, 7.5 $\mathrm{MHz}$ linear-array transrectal transducer) on d 28 and 60. Pregnancy loss was considered in cows that were pregnant on d 28 but nonpregnant on d 60 .

\section{Sampling}

During both experiments, daily milk yield for each cow was recorded automatically (AfiLite; AfiMilk), and averaged on a weekly basis. Milk samples were collected once per week from each cow during the first milking of the day $(0400 \mathrm{~h})$, and analyzed for fat and protein content using infrared spectrometry (method 972.16; AOAC International, 1999) by a commercial laboratory (Clínica do Leite; Universidade de São Paulo, Pi- 
racicaba, Brazil). Total DMI was evaluated daily, and averaged on a weekly basis, by collecting and weighing orts and subtracting from the total TMR offered within each freestall barn every day. Further, daily DMI of each freestall barn was divided by the number of cows allocated to the freestall barn on that specific day, and expressed as kilograms of DMI per cow per day. Samples of the offered and refused TMR were collected weekly from each freestall barn and dried for $48 \mathrm{~h}$ at $60^{\circ} \mathrm{C}$ in forced-air ovens for DM calculation. Weekly milk yield, FCM, and DMI of each freestall barn were used to calculate feed efficiency parameters. Samples of offered TMR were collected monthly and analyzed for nutrient content by a commercial laboratory (Nutron, Campinas, Brazil). All samples were analyzed by wet chemistry procedures for concentrations of ether extract (method 2003.05; AOAC International, 2006), CP (method 984.13; AOAC International, 2006), ADF (method 973.18 modified for use in an Ankom 200 fiber analyzer, Ankom Technology Corp., Fairport, NY; AOAC International, 2006), and NDF (Van Soest et al., 1991; modified for use in an Ankom 200 fiber analyzer, Ankom Technology Corp.). Calculations for TDN used the equation proposed by Weiss et al. (1992), whereas $\mathrm{NE}_{\mathrm{L}}$ and $\mathrm{NE}_{\mathrm{M}}$ were calculated with the equations proposed by the NRC (2001). In experiment 1, estimated duodenal flow of linoleic and linolenic acids were calculated based on DMI of each freestall barn, estimated FA profile of treatments (Table 2), and the CPM-Dairy model (version 3.08.01), which has been shown to estimate intestinal FA flow adequately in cattle (Moate et al., 2004).

Blood samples were collected from cows assigned to and concurrently with FTET, via coccygeal vein or artery into commercial blood-collection tubes (Vacutainer, 10 mL; Becton Dickinson, Franklin Lakes, NJ), placed on ice immediately, maintained at $4^{\circ} \mathrm{C}$ for 12 $\mathrm{h}$, and centrifuged at $1,500 \times \mathrm{g}$ for $15 \mathrm{~min}$ at $25^{\circ} \mathrm{C}$ for serum collection. Serum was stored at $-20^{\circ} \mathrm{C}$ until analyzed for concentrations of insulin and $\mathrm{P} 4$ using Coat-A-Count solid-phase ${ }^{125}$ I RIA kits (DPC Diagnostic Products Inc., Los Angeles, CA). Further, blood samples were only collected from cows that began receiving treatments at 30 DIM in both experiments. The intra- and interassay coefficients of variation were, respectively, 3.2 and $6.8 \%$. The minimum detectable concentrations were $0.1 \mathrm{ng}$ of $\mathrm{P} 4 / \mathrm{mL}$ and $0.05 \mu \mathrm{IU}$ of insulin/mL.

\section{Statistical Analysis}

In both experiments, performance parameters, serum variables, and services per pregnancy were analyzed with the MIXED procedure, whereas all other repro- ductive were analyzed with the GLIMMIX procedure (SAS Institute Inc., Cary, NC). All models used Satterthwaite approximation to determine the denominator degrees of freedom for the tests of fixed effects, freestall barn as the experimental unit, and cow (barn) and barn (treatment) as random variables. However, DMI, estimated duodenal flow of FA (experiment 1), and feed efficiency parameters were calculated from each freestall barn and according to the number of cows assigned to each barn; therefore, only barn (treatment) was included as random variable in these analyses. The model statement used for DIM, length of exposure to treatments before first service during the study (only cows assigned to study at DIM greater than $30 \mathrm{~d}$ ), milk production, milk content, and serum variables of all cows assigned to the experiments contained the effects of treatment, parity, week or month (serum variables) of the study, and all resultant interactions. The model statement used for DMI, feed efficiency, nutrient intake, and duodenal flow of FA contained the effects of treatment, week of the study, and all resultant interactions. The model statement used for pregnancy status and loss per service contained the effects of treatment, parity, month of the study, technique (AI or FTET), and all resultant interactions. Within cows assigned to treatments beginning at 30 DIM, the model statement used for milk production and content contained the effects of treatment, parity, week of the lactation (first 43 wk), all resultant interactions, in addition to a repeated statement containing week as specified term, cow (barn) as subject, and autoregressive as covariance structure based on the Akaike information criterion. The model statement used for service per pregnancy contained the effects of treatment, parity, month of the study, and all resultant interactions. The model statement used for pregnancy attainment contained the effects of treatment, parity, week of pregnancy attainment, and all resultant interactions. All results are reported as least squares means \pm standard error of the means and were separated using least significant difference. Significance was set at $P \leq 0.05$, tendencies were determined if $P>$ 0.05 and $\leq 0.10$. Results are reported according to main effects if no interactions were significant, or according to the highest order interaction detected.

\section{RESULTS AND DISCUSSION}

\section{Experiment 1}

Performance parameters are reported in Table 3 . During the experimental period, DIM was similar $(P$ $=0.89)$ between treatments. However, PF cows had greater $(P=0.04)$ milk yield, but had reduced $(P<$ 0.01) milk fat content compared with CON cohorts 
Table 3. Production and intake parameters of dairy cows receiving a high-concentrate diet enriched (PF) or not enriched (control) with $1.1 \%$ (DM basis) Ca salts of PUFA ${ }^{1}$

\begin{tabular}{lcccc}
\hline Item & Control & PF & SEM & $P$-value \\
\hline Production parameter $^{2}$ & & & & \\
DIM & 169 & 170 & 4 & 0.89 \\
Milk yield, kg/d & 35.3 & 37.8 & 0.7 & 0.04 \\
Milk protein, \% & 3.11 & 3.10 & 0.01 & 0.45 \\
Milk protein yield, kg/d & 1.09 & 1.16 & 0.02 & 0.12 \\
Milk fat, \% & 3.55 & 3.41 & 0.02 & $<0.01$ \\
Milk fat yield, kg/d & 1.25 & 1.27 & 0.02 & 0.61 \\
3.5\% FCM, kg/d & 35.7 & 36.2 & 0.6 & 0.61 \\
Intake parameter $^{3}$ & & & & \\
DMI, kg/d & 23.2 & 23.6 & 0.4 & 0.56 \\
Daily NE intake, MCal/d & 40.9 & 42.0 & 0.7 & 0.34 \\
Daily CP intake, $\mathrm{kg} / \mathrm{d}$ & 4.08 & 4.00 & 0.08 & 0.47 \\
Feed efficiency, $\mathrm{kg}$ of milk yield/kg of DMI & 1.55 & 1.63 & 0.04 & 0.23 \\
Feed efficiency, $\mathrm{kg}$ of FCM/kg of DMI & 1.57 & 1.56 & 0.03 & 0.93 \\
\hline
\end{tabular}

${ }^{1}$ The Ca salts of PUFA used were Megalac-E (Química Geral do Nordeste, Rio de Janeiro, Brazil).

${ }^{2}$ Milk production was recorded and collected daily, whereas milk samples were analyzed weekly for fat and protein content, from each freestall barn $(\mathrm{n}=5$ /treatment) during the experimental period (April 2009 to March 2010).

${ }^{3}$ Feed intake was monitored daily and feed efficiency parameters calculated by dividing total milk produced by total DMI consumed per freestall barn $(\mathrm{n}=5 /$ treatment $)$ on a monthly basis during the experimental period (April 2009 to March 2010).

during the experimental period. Hence, $3.5 \%$ FCM production during experiment 1 was similar $(P=0.61)$ between treatments, whereas no treatment effects were detected on milk fat yield $(P=0.61)$. Within cows assigned to treatments beginning at $30 \mathrm{DIM}$, treatment $\times$ week interactions were detected $(P<0.01)$ for milk yield and $3.5 \%$ FCM during the initial 43 wk of lactation. Cows receiving PF often had greater $(P<0.05)$ milk yield compared with CON cohorts beginning on wk 17 of lactation (Figure 1), as well as greater $(P$ $<0.05)$ FCM production (Figure 2) beginning at wk 39 of lactation. Therefore, the improved milk production detected in $\mathrm{PF}$ cows during experiment 1 can be attributed, at least partially, to potential benefits of Ca salts of PUFA on lactation persistence. Supporting our results, previous research also reported enhanced milk production (Erickson et al., 1992; Chouinard et al., 1997; Moallem et al., 2000), and reduced milk fat content (Chouinard et al., 1997; Selberg et al., 2004; Relling and Reynolds, 2007) when Ca salts of FA, including PUFA, were offered to dairy cows. Other authors also reported that feeding supplemental PUFA to dairy cows increased milk yield but did not change FCM production (Pantoja et al., 1996; AbuGhazaleh et al., 2004; Selberg et al., 2004). Milk protein has also been shown to decrease in cows receiving Ca salts of FA (Erickson et al., 1992; Harrison et al., 1995; Chouinard et al., 1997), although no treatment effects were detected herein for milk protein content $(P=0.45)$ or yield $(P=0.12)$. The benefits of Ca salts of FA supplementation on milk yield reported herein and by others is often attributed to increased energy intake in supplemented cows (Coppock and Wilks, 1991), whereas the observed decrease in milk fat content is generally attributed to altered rumen function, biohydrogenation of $\mathrm{Ca}$ salts of FA, and ruminal formation of trans C18:1 FA (Bauman and Griinari, 2003).

No treatment effects were detected on DMI $(P=$ 0.56; Table 3) during the experiment. Based on DMI of each freestall barn and nutritional profile of treatments, no treatment effects were also detected $(P \geq 0.34)$ on average daily $\mathrm{NE}_{\mathrm{L}}$ and $\mathrm{CP}$ intake (Table 3). These results indicate that inclusion of Ca salts of PUFA did not affect feed and subsequent nutrient intake. Previous studies also reported similar DMI between lactating dairy cows supplemented or not supplemented with Ca salts of FA, including PUFA (Holter et al., 1992; Schauff and Clark, 1992; Spicer et al., 1993). In fact, research has shown that DMI is not impaired in dairy cows receiving Ca salts of FA up to $5 \%$ of the diet (Moallem et al., 2000; Schroeder et al., 2003; Allred et al., 2006), whereas the inclusion rate of the Ca salts of PUFA source used herein was $1.1 \%$ (DM basis). Although cows receiving $\mathrm{PF}$ in experiment 1 had increased milk production but similar nutrient and DMI compared with CON cohorts, no treatment effects were detected $(P \geq 0.23)$ on feed efficiency parameters (Table 3). Other authors also reported that supplemental Ca salts of FA improved milk production without increasing DMI in lactating dairy cows (Erickson et al., 1992; Chouinard et al., 1997; Moallem et al., 2000). Hence, it can be concluded that the production benefits associated with Ca salts of PUFA reported herein were independent of its potential contributions to energy, 


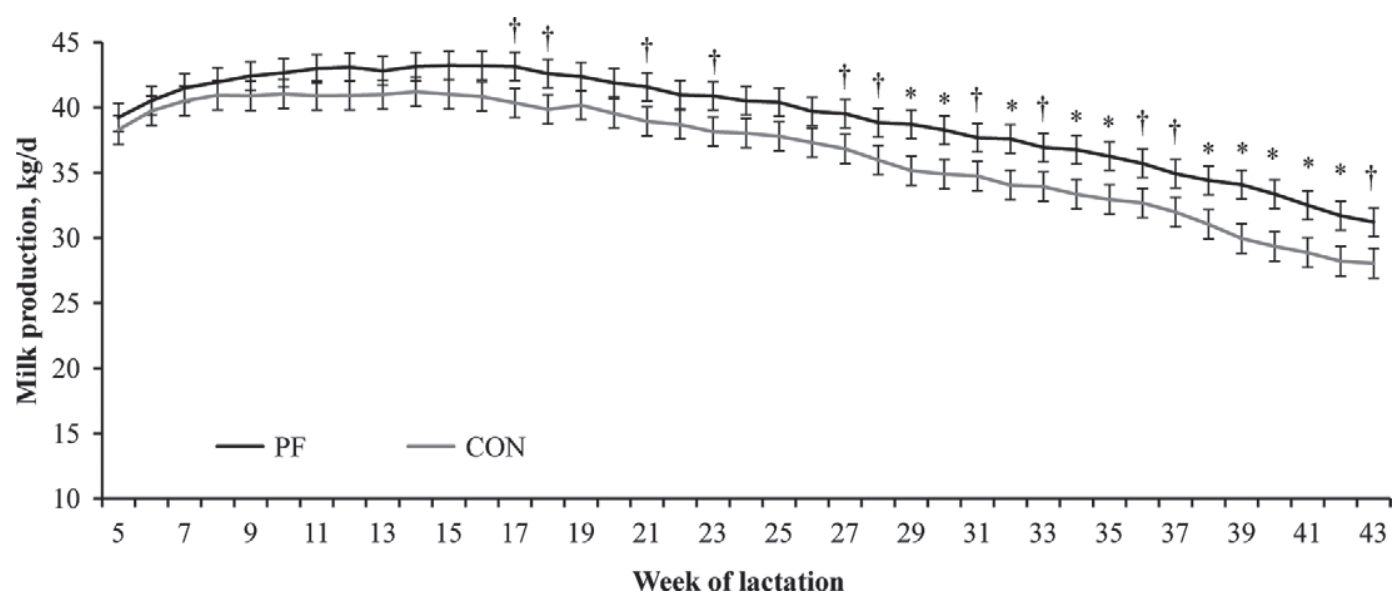

Figure 1. Milk production during the initial $43 \mathrm{wk}$ of lactation in dairy cows receiving a high-concentrate diet enriched (PF) or not enriched (control, CON) with 1.1\% (DM basis) Ca salts of PUFA (Megalac-E; Química Geral do Nordeste, Rio de Janeiro, Brazil) beginning at 30 DIM. A treatment $\times$ week interaction was detected $(P<0.01)$. Treatment comparison within time: $* P<0.05 ; \dagger P<0.10$.

protein, and overall DMI, whereas further research is warranted to identify and properly understand these mechanisms.

Reproductive parameters are reported in Table 4 . Control and PF cows with DIM greater than $30 \mathrm{~d}$ at the beginning of the study were exposed to experimental procedures during a similar $(P=0.96$; data not shown) timespan before the first service of the study (30.9 vs. 31.0 d, respectively; $\mathrm{SEM}=2.2$ ), which is adequate to modulate FA profile in reproductive tissues of dairy cattle (Mattos et al., 2000; Bilby et al., 2006). For all reproductive variables analyzed, no treatment $\times$ reproductive technique (AI or FTET) interactions were detected; therefore, results were combined between both techniques. No treatment effects were detected $(P \geq 0.43)$ on pregnancy rates per service at $\mathrm{d} 28$ or
60. However, pregnancy losses per service were reduced $(P=0.04)$ in PF cows compared with CON cohorts. Within pregnancy outcomes to the first service of each cow, no treatment effects were detected $(P \geq 0.45)$ on pregnancy status on $\mathrm{d} 28$ and 60, whereas pregnancy loss tended $(P=0.10)$ to be less in PF cows compared with CON cohorts. Within cows assigned to treatments beginning at 30 DIM, no treatment effects were detected on pregnancy attainment $(P=0.68$; data not shown), final pregnancy outcome $(P=0.51)$, or service per pregnancy $(P=0.22)$ during the experiment, although $\mathrm{PF}$ cows had reduced $(P=0.03)$ pregnancy loss upon the first service compared with CON cohorts. It is important to note that all reproductive outcomes were also analyzed with mean milk or FCM production during the week of service as covariates (data not

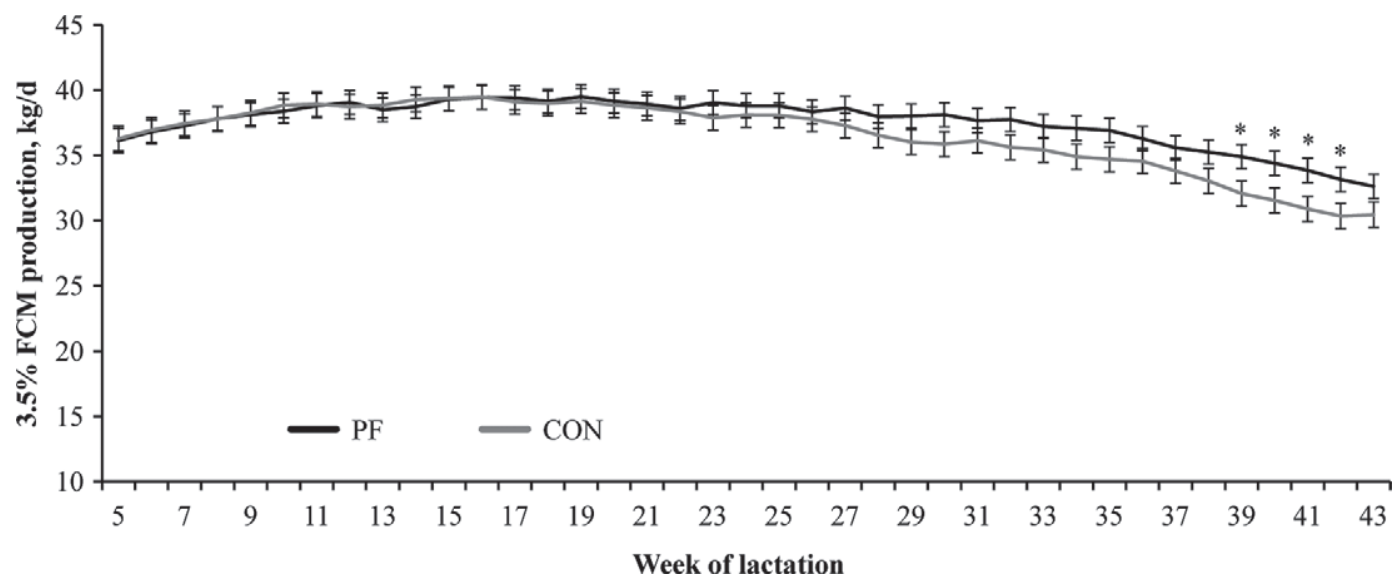

Figure 2. Fat-corrected (3.5\%) milk production during the initial $43 \mathrm{wk}$ of lactation in dairy cows receiving a high-concentrate diet enriched (PF) or not enriched (control, CON) with 1.1\% (DM basis) Ca salts of PUFA (Megalac-E; Química Geral do Nordeste, Rio de Janeiro, Brazil) beginning at 30 DIM. A treatment $\times$ week interaction was detected $(P<0.01)$. Treatment comparison within time: $* P<0.05$. 
shown); however, statistical outcomes were similar to those reported herein. These results suggest that feeding of Ca salts of PUFA to lactating dairy cows reduced pregnancy losses independent of its contribution to energy intake, although such benefit was not sufficient to increase pregnancy rates. Nevertheless, recent decreases in reproductive efficiency of dairy herds have been largely attributed to increased pregnancy losses (Zavy, 1994), whereas more than $50 \%$ of dairy cows that conceive lose their pregnancy during the initial 6 wk of gestation (Santos et al., 2004). Supporting the results reported herein, our research group recently reported that feeding of Ca salts of PUFA to beef cows after AI or ET increased pregnancy rates, whereas these outcomes were also independent of its contribution to energy intake, and attributed to enhanced pregnancy maintenance in supplemented cows (Lopes et al., 2009, 2011). It is also important to note that whole cottonseed was included at 6.0 and $11.9 \%$ of diet DM in $\mathrm{PF}$ and $\mathrm{CON}$, respectively, whereas whole cottonseed has been shown to impair reproductive performance of dairy cows (Santos et al., 2003). However, Villaseñor et al. (2008) reported that dairy heifers receiving a diet containing $11.7 \%$ of whole cottonseed had similar fertility parameters as well as embryo quality and development compared with cohorts not receiving whole cottonseed. Hence, treatment effects detected herein for pregnancy losses should not be associated with the reduced consumption of whole cottonseed by PF cows.

The mechanisms by which Ca salts of PUFA may reduce pregnancy losses include increased circulating
P4 concentrations (Stronge et al., 2005; Demetrio et al., 2007), modulation of $\mathrm{PGF}_{2 \alpha}$ synthesis and luteolysis (Williams and Stanko, 2000; Funston, 2004), and enhanced maternal recognition of pregnancy (Wathes et al., 2007). In regard to $\mathrm{P} 4$, this hormone prepares the uterine environment for conceptus growth and development, controls endometrial secretions and structural changes that are essential for proper embryo development (Gray et al., 2001; Wang et al., 2007), modulates the release of hormones that may regress the corpus luteum and disrupt gestation such as $\mathrm{PGF}_{2 \alpha}$ (Bazer et al., 1998), and is required for proper establishment of pregnancy (Spencer and Bazer, 2002). In fact, P4 concentrations after breeding were positively associated with pregnancy rates in beef and dairy cattle (Robinson et al., 1989; Stronge et al., 2005; Demetrio et al., 2007). Supplementation with PUFA increases circulating P4 by increasing circulating cholesterol availability, the major precursor for luteal P4 synthesis (Grummer and Carroll, 1991; Son et al., 1996), as well as alleviating hepatic steroid metabolism (Hawkins et al., 1995; Sangsritavong et al., 2002; Lopes et al., 2009). Moreover, Ca salts of PUFA may also increase circulating concentrations of insulin (Williams and Stanko, 2000), which in turn has also been shown to reduce hepatic expression of P4 catabolic enzymes (Lemley et al., 2008), enhance P4 synthesis by granulosa cells (Spicer et al., 1993), and improve dairy reproductive function (Gong et al., 2002). In the present experiment, however, a treatment $\times$ parity interaction was detected for serum insulin and $\mathrm{P} 4$ concentration in samples collected at the time of

Table 4. Reproductive parameters of dairy cows receiving a high-concentrate diet enriched (PF) or not enriched (control) with $1.1 \%$ (DM basis) Ca salts of PUFA ${ }^{1,2}$

\begin{tabular}{|c|c|c|c|c|}
\hline Item & Control & $\mathrm{PF}$ & SEM & $P$-value \\
\hline Pregnancy/service on d $28, \%$ & $26.5(323 / 1,306)$ & $26.1(338 / 1,411)$ & 1.4 & 0.85 \\
\hline \multicolumn{5}{|l|}{ First service $^{4}$} \\
\hline Pregnancy status on $\mathrm{d} 28, \%$ & $26.1(66 / 254)$ & $23.2(69 / 292)$ & 2.7 & 0.45 \\
\hline Pregnancy status on d $60, \%$ & $20.9(53 / 254)$ & $20.3(61 / 292)$ & 2.5 & 0.86 \\
\hline \multicolumn{5}{|c|}{ Animals assigned to treatments at $30 \mathrm{DIM}^{5}$} \\
\hline Final pregnancy rates, $\%$ & $48.1(136 / 287)$ & $45.3(150 / 330)$ & 2.8 & 0.51 \\
\hline Services per pregnancy & 2.22 & 2.05 & 0.11 & 0.27 \\
\hline Pregnancy loss to first service, $\%$ & $31.6(13 / 53)$ & $14.8(7 / 52)$ & 5.5 & 0.03 \\
\hline Pregnancy loss per service, $\%$ & $16.8(31 / 169)$ & $14.0(27 / 178)$ & 3.1 & 0.52 \\
\hline
\end{tabular}

${ }^{1}$ The Ca salts of PUFA used were Megalac-E (Química Geral do Nordeste, Rio de Janeiro, Brazil).

${ }^{2}$ Total of 1,739 AI performed in 764 cows and total of 978 fixed-time embryo transfer (ET) performed in 632 cows housed in freestall barns (n $=5$ /treatment) during the experimental period (April 2009 to March 2010). No treatment $\times$ reproductive technique (AI or fixed-time ET) interactions were detected; therefore, results were combined between both techniques. Values within parentheses correspond to the number of pregnant cows divided by the number of serviced cows.

${ }^{3}$ Pregnancy outcomes to all services during the experimental period (April 2009 to March 2010).

${ }^{4}$ Pregnancy outcomes to the first service after calving.

${ }^{5}$ Final pregnancy rates during the experimental period and number of services required per pregnancy in cows assigned to treatments beginning at 30 DIM. 
FTET (Table 5). Serum P4 concentration was greater $(P<0.01)$ and serum insulin concentration tended $(P$ $=0.08)$ to be greater in primiparous cows receiving $\mathrm{PF}$ compared with $\mathrm{CON}$ cohorts on $\mathrm{d} 7$ of the estrous cycle, whereas no treatment differences were detected within multiparous cows. Perhaps the inclusion rate of Ca salts of PUFA was sufficient to increase serum P4 and insulin in primiparous on $\mathrm{d} 7$ relative to ovulation, but not in multiparous cows. Nevertheless, Ca salts of PUFA only increased serum $\mathrm{P} 4$ and insulin in primiparous cows, but reduced pregnancy loss per service independent of parity (treatment $\times$ parity interaction; $P \geq 0.36)$. Accordingly, research from our group also suggested that serum concentrations of $\mathrm{P} 4$ and insulin $7 \mathrm{~d}$ after ovulation might not be sufficient to fully explain the benefits of Ca salts of PUFA on pregnancy maintenance (Lopes et al., 2009, 2011). Therefore, these benefits may be associated with other mechanisms not evaluated herein, including modulation of luteolysis and enhanced maternal-fetal communication (Williams and Stanko, 2000; Funston, 2004; Wathes et al., 2007).

It is also important to note that the $\mathrm{Ca}$ salts of PUFA source offered herein and in our previous research with beef cows (Lopes et al., 2009, 2011) contained significant amounts of linoleic and linolenic acids. According to the DMI of each freestall barn, estimated FA profile of treatments (Table 2), and the CPM-Dairy model (version 3.08.01), the average daily duodenal flow of linoleic and linolenic acids per cow was greater $(P<0.01$; data not shown) for PF compared with CON (73.3 vs. $50.7 \mathrm{~g}$ of linoleic acid/d, $\mathrm{SEM}=2.0$; and 5.3 vs. $3.1 \mathrm{~g}$ of linolenic acid/d, SEM $=0.1$; respectively). Linoleic acid can be desaturated and elongated to arachidonic acid and serve as a precursor for $\mathrm{PGF}_{2 \alpha}$ synthesis (Yaqoob and Calder, 2007); however, other studies also indicated that linoleic acid can reduce $\mathrm{PGF}_{2 \alpha}$ synthesis by inhibiting the enzymes $\Delta^{6}$-desaturase and cyclooxygenase (Staples et al., 1998; Cheng et al., 2001). Conversely, linolenic acid is a precursor of eicosapentaenoic and docosahexaenoic acids, which have been shown to inhibit cyclooxygenase activity and, consequently, $\mathrm{PGF}_{2 \alpha}$ synthesis (Yaqoob and Calder, 2007). Previous research demonstrated that supplementation with linoleic acid increased circulating concentrations of $\mathrm{PGF}_{2 \alpha}$ metabolite and reduced overall pregnancy rates (Filley et al., 2000; Grant et al., 2005), whereas supplementation with linolenic acid inhibited synthesis of $\mathrm{PGF}_{2 \alpha}$, delayed luteolysis, and reduced pregnancy losses in dairy and beef females (Burke et al., 1997; Thatcher et al., 1997; Mattos et al., 2000). Given that the amount and type of FA reaching target tissues dictates whether pregnancy is maintained or not (Thatcher and Staples, 2000), it cannot be concluded if Ca salts of PUFA decreased pregnancy losses herein due to the increased supply of linoleic acid, linolenic acid, or both. Moreover, the same rationale should be applied to the benefits of Ca salts of PUFA on milk production parameters reported in the present experiment. Consequently, further research is still warranted to determine the dietary levels and ratio of linoleic and linolenic acids required to effectively benefit productive and reproductive function in dairy cows.

\section{Experiment 2}

Performance parameters are reported in Table 6 . During the experimental period, mean DIM was similar $(P=0.87)$ between treatments, whereas no treatment differences were detected $(P \geq 0.39)$ on milk content and production parameters, including within cows assigned to treatments beginning at $30 \mathrm{DIM}(P \geq 0.56$; data not shown). Hence, increasing the frequency of feeding Ca salts of PUFA did not affect milk production or composition. No treatment effects were detected on DMI $(P=0.96)$ during the experiment, indicating that PF1X and PF6X cows consumed the same $(P=0.96)$ daily amount of Ca soaps of PUFA (0.250 vs. 0.251 $\mathrm{kg} / \mathrm{d}$ for PF1X and PF6X, respectively; SEM $=0.007$ ). Similarly to experiment 1 , no treatment effects were detected $(P \geq 0.76)$ on average daily $\mathrm{NE}_{\mathrm{L}}$ and $\mathrm{CP}$ intake,

Table 5. Serum insulin and progesterone of dairy cows receiving a high-concentrate diet enriched $(\mathrm{PF})$ or not enriched (control) with 1.1\% (DM basis) Ca salts of PUFA and assigned to a fixed-time embryo transfer protocol $^{1,2}$

\begin{tabular}{lcccc}
\hline Item & Control & PF & SEM & $P$-value \\
\hline Serum insulin, $\mu \mathrm{UI} / \mathrm{mL}$ & & & & \\
$\quad$ Primiparous & 7.5 & 10.4 & 1.2 & 0.08 \\
Multiparous & 9.7 & 10.3 & 0.7 & 0.51 \\
Serum progesterone, $\mathrm{ng} / \mathrm{mL}$ & & & & \\
Primiparous & 3.67 & 4.50 & 0.23 & 0.01 \\
Multiparous & 3.86 & 3.76 & 0.14 & 0.62 \\
\hline
\end{tabular}

${ }^{1}$ The Ca salts of PUFA used were Megalac-E (Química Geral do Nordeste, Rio de Janeiro, Brazil).

${ }^{2}$ Serum samples were collected in the morning before embryo transfer. 
Table 6. Production and intake parameters of dairy cows receiving a high-concentrate diet enriched with $1.1 \%$ (DM basis) of Ca salts of PUFA included in the first feeding of the day (PF1X) or equally distributed across all 6 feedings of the day $(\mathrm{PF} 6 \mathrm{X})^{1}$

\begin{tabular}{lcccc}
\hline Item & PF1X & PF6X & SEM & $P$-value \\
\hline Production parameter & & & \\
DIM & 157 & 163 & 20 & 0.87 \\
Milk yield, kg/d & 36.7 & 36.3 & 1.0 & 0.75 \\
Milk protein, \% & 2.76 & 2.77 & 0.01 & 0.39 \\
Milk protein yield, kg/d & 1.01 & 1.00 & 0.03 & 0.81 \\
Milk fat, \% & 3.08 & 3.09 & 0.02 & 0.79 \\
Milk fat yield, kg/d & 1.10 & 1.09 & 0.03 & 0.79 \\
3.5\% FCM, kg/d & 35.2 & 34.8 & 1.1 & 0.79 \\
Intake parameter & & & & \\
DMI, kg/d & 22.7 & 22.8 & 0.6 & 0.96 \\
Daily NE intake, MCal/d & 40.5 & 40.5 & 1.1 & 0.97 \\
Daily CP intake, kg/d & 3.85 & 3.86 & 0.10 & 0.96 \\
Feed efficiency, kg of milk yield/kg of DMI & 1.61 & 1.59 & 0.04 & 0.78 \\
Feed efficiency, kg of FCM/kg of DMI & 1.54 & 1.52 & 0.04 & 0.76 \\
\hline
\end{tabular}

${ }^{1}$ The Ca salts of PUFA used were Megalac-E (Química Geral do Nordeste, Rio de Janeiro, Brazil).

${ }^{2}$ Milk production was recorded and collected daily, whereas milk samples were analyzed weekly for fat and protein content, from each freestall barn $(\mathrm{n}=5$ /treatment) during the experimental period (April 2009 to March 2010).

${ }^{3}$ Feed intake was monitored daily and feed efficiency parameters calculated by dividing total milk produced by total DMI consumed per freestall barn $(\mathrm{n}=5$ /treatment $)$ on a monthly basis during the experimental period (April 2009 to March 2010).

as well as on feed efficiency parameters (Table 6), suggesting that frequency of Ca salts of PUFA inclusion in the TMR did not affect nutrient intake and utilization. Therefore, Ca salts of PUFA can be fed once per day, or included in every TMR feeding, without affecting feed intake and overall production parameters of lactating dairy cows (Coppock and Wilks, 1991; Bauman and Griinari, 2003).

Reproductive parameters are reported in Table 7 . As in experiment 1, PF1X and PF6X cows with DIM greater than $30 \mathrm{~d}$ at the beginning of the study were exposed to experimental procedures during a similar $(P=$ 0.93; data not shown) timespan before the first service of the study (26.1 vs. 26.4 d, respectively; $\mathrm{SEM}=2.2$ ), which is adequate to modulate FA profile in reproductive tissues of dairy cattle (Mattos et al., 2000; Bilby et al., 2006). No treatment $\times$ reproductive technique (AI or FTET) interactions were detected; therefore, results were combined between both techniques. No treatment effects were detected $(P \geq 0.45)$ on pregnancy rates per service at d 28 or 60 . However, pregnancy losses per service tended $(P=0.09)$ to be reduced in PF1X cows compared with PF6X cohorts. Within pregnancy outcomes to the first service of each cow, no treatment effects were detected $(P \geq 0.41)$ on pregnancy status on d 28 and 60 or pregnancy loss. No treatment effects were detected on pregnancy attainment $(P=0.60$; data not shown), final pregnancy outcome $(P=0.48)$, service per pregnancy $(P=0.22)$, or pregnancy loss $(P \geq$ 0.21 ) within cows assigned to treatments beginning at 30 DIM during experiment 2 . These results suggest that reducing the feeding frequency of Ca salts of PUFA to lactating dairy cows benefited reproduction by reducing pregnancy losses. Moreover, this reproductive benefit was independent of nutrient intake and milk production, but not sufficient to increase pregnancy rates. One can speculate that feeding Ca salts of PUFA during the first feeding of the day alleviated ruminal dissociation and consequent biohydrogenation of these FA. Calcium salts of PUFA can be substantially dissociated and biohydrogenated when ruminal $\mathrm{pH}$ is below 6.0 (Sukhija and Palmquist, 1990), whereas ruminal $\mathrm{pH}$ in dairy cows receiving high-concentrate TMR may be greater than 6.0 before and for the first hours after the morning feeding (Maekawa et al., 2002). Hence, PF1X cows may have experienced greater absorption and incorporation of PUFA compared with PF6X cohorts, leading to treatment differences detected for pregnancy loss per service. However, rumen $\mathrm{pH}$, ruminal biohydrogenation, and PUFA concentrations in serum or tissues were not evaluated herein to support these assumptions.

No treatment effects were detected on serum P4 $(P$ $=0.31$; data not shown $)$ or insulin $(P=0.94$; data not shown) concentrations (3.44 vs. $3.58 \mathrm{ng}$ of $\mathrm{P} 4 / \mathrm{mL}$, $\mathrm{SEM}=0.10$; and 7.2 vs. $7.0 \mu \mathrm{UI}$ of insulin $/ \mathrm{mL}, \mathrm{SEM}=$ 1.2, for PF1X and PF6X cows, respectively) in samples collected at the time of FTET. The results indicate that frequency of Ca salts of PUFA inclusion into the TMR did not affect circulating concentrations of these hormones on d 7 of the estrous cycle. Similarly to experiment 1 , the decrease in pregnancy loss per service detected herein was independent of treatment effects 
Table 7. Reproductive parameters of dairy cows receiving a high-concentrate diet enriched with 1.1\% (DM basis) Ca salts of PUFA included in the first feeding of the day (PF1X) or equally distributed across all 6 feedings of the day $(\mathrm{PF} 6 \mathrm{X})^{1,2}$

\begin{tabular}{|c|c|c|c|c|}
\hline Item & PF1X & PF6X & SEM & $P$-value \\
\hline Pregnancy/service on $\mathrm{d} 28, \%$ & $25.3(529 / 2,135)$ & $25.2(521 / 2,080)$ & 0.9 & 0.96 \\
\hline \multicolumn{5}{|l|}{ First service $^{4}$} \\
\hline Pregnancy status on $\mathrm{d} 28, \%$ & $24.1(139 / 578)$ & $22.1(127 / 570)$ & 1.7 & 0.41 \\
\hline Pregnancy status on d $60, \%$ & $20.2(116 / 578)$ & $19.1(110 / 570)$ & 1.7 & 0.66 \\
\hline \multicolumn{5}{|c|}{ Animals assigned to treatments at $30 \mathrm{DIM}^{5}$} \\
\hline Final pregnancy rates, $\%$ & $56.0(302 / 539)$ & $54.0(293 / 544)$ & 2.0 & 0.48 \\
\hline Services per pregnancy & 2.66 & 2.64 & 0.10 & 0.90 \\
\hline Pregnancy loss to first service, $\%$ & $18.4(22 / 132)$ & $11.7(16 / 116)$ & 3.7 & 0.21 \\
\hline Pregnancy loss per service, $\%$ & $15.0(61 / 380)$ & $14.8(61 / 374)$ & 4.0 & 0.95 \\
\hline
\end{tabular}

${ }^{1}$ The Ca salts of PUFA used were Megalac-E (Química Geral do Nordeste, Rio de Janeiro, Brazil).

${ }^{2}$ Total of 3,044 AI performed in 1,133 cows and total of 1,171 fixed-time embryo transfer (ET) performed in 697 cows housed in freestall barns $(\mathrm{n}=5 /$ treatment) during the experimental period (April 2010 to June 2011). No treatment $\times$ reproductive technique (AI or fixed-time ET) interactions were detected; therefore, results were combined between both techniques. Values within parentheses correspond to the number of pregnant cows divided by number of serviced cows.

${ }^{3}$ Pregnancy outcomes to all services during the experimental period (April 2010 to June 2011).

${ }^{4}$ Pregnancy outcomes to the first service after calving.

${ }^{5}$ Final pregnancy rates during the experimental period, and number of services required per pregnancy in cows assigned to treatments beginning at 30 DIM.

on circulating P4 and insulin (Lopes et al., 2009, 2011), and may be associated with other mechanisms such as modulation of luteolysis and enhanced maternal-fetal communication (Williams and Stanko, 2000; Funston, 2004; Wathes et al., 2007).

\section{CONCLUSIONS}

Feeding Ca salts of PUFA to lactating dairy cows increased milk production and reduced pregnancy losses per service, although such benefit was not sufficient to increase pregnancy rates. Further, frequency of Ca salts of PUFA inclusion did not affect intake and production parameters, but should be completely fed during the first feeding of the day to optimize its benefits to pregnancy maintenance in lactating dairy cows. However, the mechanisms associating Ca salts of PUFA with the productive and reproductive benefits reported herein, as well as optimal dietary levels and ratio of linoleic and linolenic acids, still warrant further investigation. Nevertheless, feeding Ca salts of PUFA is a feasible alternative to enhance milk production and benefit, or at least prevent a decrease, in reproductive efficiency of high-producing lactating dairy cows.

\section{ACKNOWLEDGMENTS}

Appreciation is extended to Tatiana Araujo (Química Geral do Nordeste, Rio de Janeiro, Brazil) for providing the Megalac-E fed in the present experiments.

\section{REFERENCES}

AbuGhazaleh, A. A., D. J. Schingoethe, A. R. Hippen, and K. F. Kalscheur. 2004. Conjugated linoleic acid increases in milk when cows fed fish meal and extruded soybeans for an extended period of time. J. Dairy Sci. 87:1758-1766.

Allred, S. L., T. R. Dhiman, C. P. Brennand, R. C. Khanal, D. J. McMahon, and N. D. Luchini. 2006. Milk and cheese from cows fed calcium salts of palm and fish oil alone or in combination with soybean products. J. Dairy Sci. 89:234-248.

AOAC International. 1999. Official Method of Analysis. 16th ed. AOAC International, Arlington, VA

AOAC International. 2006. Official Methods of Analysis. 18th ed AOAC International, Arlington, VA.

Bauman, D. E., and J. M. Griinari. 2003. Nutritional regulation of milk fat synthesis. Annu. Rev. Nutr. 23:203-227.

Bazer, F. W., T. E. Spencer, and T. L. Ott. 1998. Endocrinology of the transition from recurring estrous cycles to establishment of pregnancy in subprimate mammals. Pages 1-34 in The Endocrinology of Pregnancy. F. W. Bazer, ed. Humana Press Inc., Totowa, NJ.

Bilby, T. R., T. Jenkins, C. R. Staples, and W. W. Thatcher. 2006. Pregnancy, bovine somatotropin, and dietary n-3 fatty acids in lactating dairy cows: III. Fatty acid distribution. J. Dairy Sci. 89:3386-3399.

Burke, J. M., C. R. Staples, C. A. Risco, R. L. De La Sota, and W W. Thatcher. 1997. Effects of feeding a ruminant grade Menhaden fish meal on reproductive and productive performance of lactating dairy cows. J. Dairy Sci. 80:3386-3398.

Butler, W. R. 2005. Inhibition of ovulation in the postpartum cow and the lactating sow. Livest. Prod. Sci. 98:5-12.

Cheng, Z., R. S. Robinson, P. G. A. Pushpakumara, R. J. Mansbridge, and D. C. Wathes. 2001. Effect of dietary polyunsaturated fatty acids on uterine prostaglandin synthesis in the cow. J. Endocrinol. 171:463-473.

Chouinard, P. Y., V. Girard, and G. J. Brisson. 1997. Lactational response of cows to different concentrations of calcium salts of canola oil fatty acids with or without bicarbonates. J. Dairy Sci. 80:1185-1193.

Coppock, C. E., and D. L. Wilks. 1991. Supplemental fat in highenergy rations for lactating cows: Effects on intake, digestion, milk yield, and composition. J. Anim. Sci. 69:3826-3837. 
Demetrio, D. G. B., R. M. Santos, C. G. B. Demetrio, and J. L. M. Vasconcelos. 2007. Factors affecting conception rates following artificial insemination or embryo transfer in lactating Holstein cows. J. Dairy Sci. 90:5073-5082.

Erickson, P. S., M. R. Murphy, and J. H. Clark. 1992. Supplementation of dairy cow diets with calcium salts of long-chain fatty acids and nicotinic acid in early lactation. J. Dairy Sci. 75:1078-1089.

FASS (Federation of Animal Science Societies). 1999. Guide for the Care and Use of Agricultural Animals in Agricultural Research and Teaching. 1st rev. ed. Federation of Animal Science Societies, Savoy, IL

Filley, S. J., H. A. Turner, and F. Stormshak. 2000. Plasma fatty acids, prostaglandin $\mathrm{F}_{2 \alpha}$ metabolite, and reproductive response in postpartum heifers fed rumen bypass fat. J. Anim. Sci. 78:139-144.

Funston, R. N. 2004. Fat supplementation and reproduction in beef females. J. Anim. Sci. 82(E. Suppl.):E154-E161.

Gong, J. G., W. J. Lee, P. C. Garnsworthy, and R. Webb. 2002. Effect of dietary-induced increases in circulating insulin concentrations during the early postpartum period on reproductive function in dairy cows. Reproduction 123:419-427.

Grant, M. H. J., B. M. Alexander, B. W. Hess, J. D. Bottger, D. L. Hixon, E. A. Van Kirk, T. M. Nett, and G. E. Moss. 2005. Dietary supplementation with safflower seeds differing in fatty acid composition differentially influences serum concentrations of prostaglandin $\mathrm{F}$ metabolite in postpartum beef cows. Reprod. Nutr. Dev. 45:721-727.

Gray, C. A., K. M. Taylor, W. S. Ramsey, J. R. Hill, F. W. Bazer, F. F. Bartol, and T. E. Spencer. 2001. Endometrial glands are required for preimplantation conceptus elongation and survival. Biol. Reprod. 64:1608-1613.

Grummer, R. R., and D. J. Carroll. 1991. Effects of dietary fat on metabolic disorders and reproductive performance of dairy cattle. J. Anim. Sci. 69:3838-3852.

Harrison, J. H., R. L. Kincaid, J. P. McNamara, S. Waltner, K. A. Loney, R. E. Riley, and J. D. Cronrath. 1995. Effect of whole cottonseeds and calcium salts of long-chain fatty acids on performance of lactating dairy cows. J. Dairy Sci. 78:181-193.

Hawkins, D. E., K. D. Niswender, G. M. Oss, C. L. Moeller, K. G. Odde, H. R. Sawyer, and G. D. Niswender. 1995. An increase in serum lipids increases luteal lipid content and alters the disappearance rate of progesterone in cows. J. Anim. Sci. 73:541-545.

Holter, J. B., H. H. Hayes, W. E. Urban Jr., and A. H. Duthie. 1992. Energy balance and lactation response in Holstein cows supplemented with cottonseed with or without calcium soap. J. Dairy Sci. $75: 1480-1494$.

Leedle, J. A., M. P. Bryant, and R. B. Hespell. 1982. Diurnal variations in bacterial numbers and fluid parameters in ruminal contents of animals fed low- or high-forage diets. Appl. Environ. Microbiol. 44:402-412.

Lemley, C. O., S. T. Butler, W. R. Butler, and M. E. Wilson. 2008 Short communication: Insulin alters hepatic progesterone catabolic enzymes cytochrome P450 2C and 3A in dairy cows. J. Dairy Sci. 91:641-645.

Lopes, C. N., R. F. Cooke, M. M. Reis, R. F. G. Peres, and J. L. M. Vasconcelos. 2011. Strategic supplementation of rumen-protected polyunsaturated fatty acids to enhance reproductive performance of Bos indicus beef cows. J. Anim. Sci. 89:3116-3124.

Lopes, C. N., A. B. Scarpa, B. I. Cappellozza, R. F. Cooke, and J. L. M. Vasconcelos. 2009. Effects of rumen-protected polyunsaturated fatty acid supplementation on reproductive performance of Bos indicus beef cows. J. Anim. Sci. 87:3935-3943.

Lucy, M. C. 2001. Reproductive loss in high-producing dairy cattle: Where will end? J. Dairy Sci. 84:1277-1293.

Lucy, M. C., C. R. Staples, F. M. Michel, W. W. Thatcher, and D. J. Bolt. 1991. Effect of feeding calcium soaps to early postpartum dairy cows on plasma prostaglandin $\mathrm{F}_{2 \alpha}$, luteinizing hormone, and follicular growth. J. Dairy Sci. 74:483-489.

Maekawa, M., K. A. Beauchemin, and D. A. Christensen. 2002. Effect of concentrate level and feeding management on chewing activities, saliva production, and ruminal $\mathrm{pH}$ of lactating dairy cows. J. Dairy Sci. 85:1165-1175.
Mattos, R., C. R. Staples, and W. W. Thatcher. 2000. Effects of dietary fatty acids on reproduction in ruminants. Rev. Reprod. 5:38-45.

Moallem, U., Y. Folman, and D. Sklan. 2000. Effects of somatotropin and dietary calcium soaps of fatty acids in early lactation on milk production, dry matter intake, and energy balance of high-yielding dairy cows. J. Dairy Sci. 83:2085-2094.

Moate, P. J., W. Chalupa, T. C. Jenkins, and R. C. Boston. 2004. A model to describe ruminal metabolism and intestinal absorption of long chain fatty acids. Anim. Feed Sci. Technol. 112:79-105.

NRC. 2001. Nutrient Requirements of Dairy Cattle. Natl. Acad. Sci., Washington, DC.

Pantoja, J., J. L. Firkins, and M. L. Eastridge. 1996. Fatty acid digestibility and lactation performance by dairy cows fed fats varying in degree of saturation. J. Dairy Sci. 79:429-437.

Relling, A. E., and C. K. Reynolds. 2007. Feeding rumen-inert fats differing in their degree of saturation decreases intake and increases plasma concentrations of gut peptides in lactating dairy cows. J. Dairy Sci. 90:1506-1515.

Robinson, N. A., K. E. Leslie, and J. S. Walton. 1989. Effect of treatment with progesterone on pregnancy rate and plasma concentrations of progesterone in Holstein cows. J. Dairy Sci. 72:202-207.

Sangsritavong, S., D. G. Mashek, A. Gumen, J. M. Haughian, R. R. Grummer, and M. C. Wiltbank. 2002. Metabolic clearance rate of progesterone and estradiol-17 $\beta$ is decreased by fat. J. Anim. Sci. 80(Suppl. 1):142. (Abstr.)

Santos, J. E. P., W. W. Thatcher, R. C. Chebel, R. L. A. Cerri, and K. N. Galvão. 2004. The effect of embryonic death rates in cattle on the efficacy of estrus synchronization programs. Anim. Reprod. Sci. 82-83:513-535.

Santos, J. E. P., M. Villasenor, P. H. Robinson, E. J. DePeters, and C. A. Holmberg. 2003. Type of cottonseed and level of gossypol in diets of lactating dairy cows: Plasma gossypol, health, and reproductive performance. J. Dairy Sci. 86:892-905.

Schauff, D. J., and J. H. Clark. 1992. Effect of feeding diets containing calcium salts of long-chain fatty acids to lactating dairy cows. J. Dairy Sci. 75:2990-3002.

Schroeder, G. F., J. E. Delahoy, I. Vidaurreta, F. Bargo, G. A. Gagliostro, and L. D. Muller. 2003. Milk fatty acid composition of cows fed a total mixed ration or pasture plus concentrates replacing corn with fat. J. Dairy Sci. 86:3237-3248.

Selberg, K. T., A. C. Lowe, C. R. Staples, N. D. Luchini, and L. Badinga. 2004. Production and metabolic responses of periparturient Holstein cows to dietary conjugated linoleic acid and trans-octadecenoic acids. J. Dairy Sci. 87:158-168.

Son, J., R. J. Grant, and L. L. Larson. 1996. Effects of tallow and escape protein on lactational and reproductive performance of dairy cows. J. Dairy Sci. 79:822-830.

Spencer, T. E., and F. W. Bazer. 2002. Biology of progesterone action during pregnancy recognition and maintenance of pregnancy. Front. Biosci. 7:d1879-d1898.

Spicer, L. J., E. Alpizar, and S. E. Echternkamp. 1993. Effects of insulin, insulin-like growth factor I, and gonadotropins on bovine granulosa cell proliferation, progesterone production, estradiol production, and(or) insulin-like growth factor I production in vitro. J. Anim. Sci. 71:1232-1241

Spicer, L. J., R. K. Vernon, W. E. Tucker, R. P. Wettemann, J. F. Hogue, and G. D. Adams. 1993. Effects of inert fat on energy balance, plasma concentrations of hormones, and reproduction in dairy cows. J. Dairy Sci. 76:2664-2673.

Staples, C. R., J. M. Burke, and W. W. Thatcher. 1998. Influence of supplemental fats on reproductive tissues and performance of lactating cows. J. Dairy Sci. 81:856-871.

Staples, C. R., and W. W. Thatcher. 2005. Effects of fatty acids on reproduction of dairy cows. Pages 229-256 in Recent Advances in Animal Nutrition 2005. P. C. Garnsworthy and J. Wiseman, ed. Nottingham University Press, Nottingham, UK.

Stronge, A. J. H., J. M. Sreenan, M. G. Diskin, J. F. Mee, D. A. Kenny, and D. G. Morris. 2005. Post-insemination milk progesterone concentration and embryo survival in dairy cows. Theriogenology 64:1212-1224. 
Sukhija, P. S., and D. L. Palmquist. 1990. Dissociation of calcium soaps of long-chain fatty acids in rumen fluid. J. Dairy Sci. 73:1784-1787.

Thatcher, W. W., M. Binelli, J. Burke, C. R. Staples, J. D. Ambrose, and S. Coelho. 1997. Antiluteolytic signals between the conceptus and endometrium. Theriogenology 47:131-140.

Thatcher, W. W., and C. R. Staples. 2000. Effects of dietary fat supplementation on reproduction in lactating dairy cows. Adv. Dairy Technol. 12:213-232.

Van Soest, P. J., J. B. Robertson, and B. A. Lewis. 1991. Methods for dietary fiber, neutral detergent fiber, and nonstarch polysaccharides in relation to animal nutrition. J. Dairy Sci. 74:3583-3597.

Vasconcelos, J. L. M., D. T. G. Jardina, O. G. Sá Filho, F. L. Aragon, and M. B. Veras. 2011. Comparison of progesterone-based protocols with gonadotropin-releasing hormone or estradiol benzoate for timed artificial insemination or embryo transfer in lactating dairy cows. Theriogenology 75:1153-1160.

Vieira, F. V. R., C. N. Lopes, B. I. Cappellozza, A. B. Scarpa, R. F. Cooke, and J. L. M. Vasconcelos. 2010. Effects of intravenous glucose infusion and nutritional balance on serum concentrations of NEFA, glucose, insulin, and progesterone in non-lactating dairy cows. J. Dairy Sci. 93:3047-3055.
Villaseñor, M., A. C. Coscioni, K. N. Galvão, R. C. Chebel, and J. E. P. Santos. 2008. Gossypol disrupts embryo development in heifers. J. Dairy Sci. 91:3015-3024.

Wang, C. K., R. S. Robinson, A. P. Flint, and G. E. Mann. 2007. Quantitative analysis of changes in endometrial gland morphology during the bovine oestrous cycle and their association with progesterone levels. Reproduction 134:365-371.

Wathes, D. C., D. Robert, E. Abayasekara, and R. J. Aitken. 2007. Polyunsaturated fatty acids in male and female reproduction. Biol. Reprod. 77:190-201.

Weiss, W. P., H. R. Conrad, and N. R. St. Pierre. 1992. A theoretically-based model for predicting total digestible nutrient values of forages and concentrates. Anim. Feed Sci. Technol. 39:95-110.

Williams, G. L., and R. L. Stanko. 2000. Dietary fats as reproductive nutraceuticals in beef cattle. J. Anim. Sci. 77(E. Suppl.):1-12.

Yaqoob, P., and P. C. Calder. 2007. Fatty acids and immune function: new insights into mechanisms. Br. J. Nutr. 98(Suppl. 1):S41-S45.

Zavy, M. T. 1994. Embryonic mortality in cattle. Pages 99-140 in Embryonic Mortality in Domestic Species. M. T. Zavy and R. D. Geisert, ed. CRC Press, Boca Raton, FL. 